\title{
Strategi Promosi Destinasi Wisata Edukasi Taman Nusa Tulikup Gianyar
}

\author{
Firlie Lanovia Amir'1),Komang Shanty Muni Parwati' ${ }^{2)}$, Gusti Ngurah Yoga Semadi ${ }^{3)}$ \\ Ni Wayan Mega Sari Apri Yani ${ }^{4}$
}

\author{
Institut Pariwisata dan Bisnis Internasional, Jalan Tari Kecak No. 12 Denpasar 80239 \\ Telp/Fax : (0361) 426699, E-mail : humas@ipb-intl.ac.id \\ E-mail: firlie@ipb-intl.ac.id ${ }^{1)}$
}

\begin{abstract}
Abstrak
Tujuan dari penelitian ini a dalah untuk mengetahui strategi promosi destinasi wisa ta edukasi yang a da di Taman Nusa Tulikup Gianyar. Penelitian ini merupakan penelitian awal dari langkah-langkah strategi pengembangan suatu daya tarik wisata dengan tujuan utama wisatawan. Pendekatan yang dila kukan adalah secara kualitatif, dengan mengacu pa da teori Promosi dan Teori Destinasi Wisa ta. Agar tersebar merata, dan mendapatkan data yang komprehensif, fokus penelitian berada pada Taman Nusa di Desa Sidan. Pendekatan yang dilakukan adalah secara kualitatif, dengan mengacu pada teori Promosi dan Teori Destinasi Wisata. Agar tersebar merata, dan mendapatkan data yang komprehensif, fokus penelitia n berada pada Taman Nusa diDesa Sidan, Ka bupaten Gianyar. Data a kan dikumpulkan melalui wawancara, studi kepustakaan diharapkan, secara akademis, penelitian ini mampu mengkaji dan mengeksplorasi lebih dalamberkenaan dengan la tar belakang, pola-pola sosialisasi yang diterapkan, dan implikasinya terha dap masyarakat setempat juga wisatawan khusu snya yang berkunjung ke Taman Nusa yang beradadi Desa Sidan, Gianyar. Kemudian diharapkan juga dapat menjadi salah satu sumbangan pemikiran dalam pengembangan kepa riwisataan yang berbasis budaya yang inovatif, kreatif, dan berkesinambungan.
\end{abstract}

Kata Kunci: Wisata Edukasi, Strategi Promosi, TamanNusa

\begin{abstract}
The purpose of this study was to determine the promotion strategy of educational tourism destinations in Taman Nusa Tulikup Gianyar. This research is a preliminary study of the strategic steps of developing a tourist attraction with the main goal of tourists. The approach taken is qua litative, with reference to the theory of Promotion and Tourism Destination Theory. In order to be evenly distributed, and to obtain comprehensive data, the focus of the research is on Ta man Nu sa in Sidan Villa ge. Data will be colla ge throu gh interviews, literature studies are ex pected academically, this resea rch is able to examine and explore more deeply with respect to the background, patterns of socialization that are applied, and their implication for the local community as well a s tourists, especially those who visit Taman Nusa in the village Sidan, Gianyar. Then it is hoped that it can also be one of the contributions of thought in developing innovative, creative, and sustainable culture-based tourism.
\end{abstract}

Keyword : Educational Tourism, Promotion Strategy, Taman Nusa

\section{PENDAHULUAN}

Industri pariwisata menjadi andalan selama lebih dari satu decade sebagai salah satu sumber devisa di Indonesia. Keberadaan industry hospitality juga turut mendorong berbagai perkembangan secara global di pelbagai belahan dunia. Dampaknya sangat dirasakan oleh negara dan masyarakat yang dilanda, khususnya di negara-negara yang sedang berkembang, seperti Indonesia. Bali sebagai salah satu daerah industri pariwisata tidak bisa lepas dari besarnya arus globalisasi. Wisatawan asing dari manca negara berdatangan ke Bali untuk menikmati wisata budaya, alam dan religi.

Bali sebagai destinasi terkenal di dunia karena kebudayaannya, fasilitas pendukung dianggap paling lengkap dibandingkan dengan destinasi wisata lain di Indonesia. Dengan perkembangan pariwisata yang sudah memasuki dekade ke 4, berbagai atraksi wisata bermunculan untuk keterbaharuan bagi para 
wisatawan. Kebiasaan dan kebudaayan yang berbeda, menjadi ciri khas yang ditawarkan sehingga wisatawan selalu memilih Bali sebagai destinasi wisata yang wajib dikunjungi, tidak hanya bagi wisatawan mancanegara, tetapi juga bagi wisatawan domestik dan lokal yang ingin mengexplorasi daerah-daerah yang selama ini belum termasuk ke dalam destinasi pilihan utama dalam berwisata.

Perkembangan pariwisata pulau dewata saat ini telah mengalami perkembangan yang sedemikian pesat baik dari objek wisata dan fasilitas pendukungnya. Kabupaten Gianyar, yang sudah memiliki Ubud sebagai destinasi utama, kini telah berupaya untuk mengembangkan salah satu tujuan wisata bagian timur yaitu Taman Nusa, atau dikenal sebagai taman mininya Indonesia yang berada di Bali. Keanekaragaman nusantara yang dapat dijumpai wisatawan selama berlibur di Bali yang hanya dibutuhkan kurang dari satu hari dengan berkeliling melihat aneka kebudayaan sebagai perwakilan dari corak budaya yang ada di berbagai daerah di Indonesia.

Taman Nusa yang terletak di Desa Sidan, Kecamatan Gianyar, Kabupaten Gianyar merupakan salah satu dari 8 kabupaten yang ada di Bali. Destinasi wisata ini merupakan salah satu atraksi wisata yang memperkenalkan beberapa budaya terkenal yang ada di beberapa sumber budaya di kepulauan Nusantara. Keunggulan Taman Nusa bertumpu pada potensi seni budaya, arsitektur dan yang lainnya perlu diperkenalkan kepada wisatawan umum yang bercekimpung dalam hal pariwisata sehingga lebih dikenal lagi ke manca negara. Selama ini keberadaan Taman Nusa sebagai tujuan wisata bagian Timur Gianyar, belumlah banyak dikenal oleh wisatawan baik dalam maupun luar negeri, maka penelitian ini diperlukan guna ikut mempromosikan keberadaan Taman Nusa ini. Hal ini sangat membantu masyarakat Indonesia khususnya Bali karena wisata merupakan salah satu tumpuan hidup masyarakat Bali.

\section{METODE PENELITIAN}

Penelitian yang dilakukan pada Taman Nusa ini penelitian ini dilakukan dengan pendekatan kualitatif, dengan mempergunakan pendekatan alam budaya dan dan sosio kultural yang dikaji adalah latar belakang adanya Taman Nusa serta peran managemen dalam usaha mengembangkan wisata tersebut. Kesesuaian studi pustaka dengan judul penelitian yang akan dibahas, yakni sama-sama melihat dari perspektif managemennya dan juga wisatawan yang berkunjung baik lokal maupun internasional, yakni dari segi karakternya, motivasi, pengalaman selama berwisata. Kemudian yang lebih penting adalah masyarakat Desa Sidan mencakup impilakinya bagi masyarakat sekitarnya. Meskipun demikian, penelitian ini menonjolkan kebaharuan yakni dengan menargetkan pada wisata edukasi di Bali. yang mana belum ada penelitian yang mengambil fokus penelitian terhadap masalah ini.

Jenis data yang digunakan pada penelitian ini yaitu : data Kualitatif dengan data yang dikumpulkan dari hasil wawancara mengenai gambaran umum perusahaan, struktur organisasi, dan tata kerja managemen perusahaan.

Dalam penelitian ini yang dipergunakan adalah data primer dan data sekunder.

Sumber data yang digunakan dalam penelitian ini adalah sebagai berikut:

1. Data primer didapat dari hasil wawancara yang dilakukan secara langsung dengan tokoh-tokoh masyarakat yang terkait, juga karyawan atau tenaga kerja di areal Taman Nusa, pegawai, pengunjung, sebagai sumber data

2. Data sekunder yang diperoleh dari sumber internal, yaitu data tentang lokasi dan gambaran umum sejarah berdirinya Taman Nusa.

Metode pengumpulan data menggunakan 3 metode yaitu: wawancara, observasi, dan studi kepustakaan.

Teknik analisis data yang digunakan pada penelitian ini adalah mengacu pada model Miles dan Huberman, dengan tiga tahapan berikut:

1. Reduksi data, yakni mengeliminasi data yang tidak valid

2. Penyajian data, menyajikan data untuk menjawab rumusan masalah dan melakukan pembahasan dikaitkan dengan teori yang digunakan

3. Penarikan kesimpulan, membuat kesimpulan sesuai dengan hasil pembahasan 


\section{HASIL DAN PEMBAHASAN}

Berdasarkan rumusan masalah yang diteliti oleh penulis, penulis mendapatkan hasil keseluruhan dari 3 hal yaitu Strategi Promosi, Proses Pengembangan Taman Nusa Sebagai Wisata Edukasi, dan Implikasi Masyarakat Sekitar terhadap Eksistesi Taman Nusa dan Wisatawan sebagai berikut:

Terdapat lebih dari 60 rumah tradisional yang disebut kampong budaya, sebagian diantaranya telah berumur hingga ratusan tahun. Pengunjung berkesempatan mengenal berbagai etnis, budaya dan kerajinan serta kesenian Indonesia. Berikutnya memasuki Indonesia awal terdapat patuh Mahapatih Gajah Mada, Candi Trowulan dan Gapura Supah Pemuda yang memberi inspirasi persatuan Indonesia. Kemudian memasuki Indonesia Merdeka dengan adanya patung proklamator Bapak Soekarno dan Bung Hatta serta teks Proklamasi Indonesia Merdeka.

Strategi Promosi Destinasi Wisata Taman Nusa Sebagai Wisata Edukasi yang dilakukan adalah Pemanfaatan Media Sosial, Sosialisasi Melalui Kunjungan Langsung Wisatawan, kemudian dengan pemanfaatan media sosial sebagai sarana untuk promosi merupakan suatu pola strategis yang memiliki banyak kelebihan. Setelah tutup sekitar 5 (lima) bulan dan di buka kembali pada tanggal 2 Agusutus 2020, kunjungan wisata sekitar kurang lebih 100 orang dibanding sebelum pandemi terjadi kunjungan mencapai ribuan orang. Untuk promosi selama ini tetap disebarluaskan melalui media sosial, seperti Website, Facebook, Twitter dan sejenisnya. Selain melalui sosial media dicetak pula brosur-brosur dan disebar dibeberapa intansi yang terkait, ke sekolah-sekolah dan kampus-kampus yang ada di Bali juga di luar Bali. Disamping hal tersebut, promosi juga terjadi secara personal selling, dari mulut ke mulut. Wisatawan yang berkunjung ke Taman Nusa, tidak sedikit diantaranya adalah orang-orang terpelajar. Setelah mendapatkan penjelasan secara sederhana lalu mereka ingin mengembangkan diri melalui kreativitas yang ada di wisata ini dengan melibatkan diri untuk melakukan workshop sehingga ada bekal Ketika mereka kembali ke negara mereka masing-masing. Berikutnya proses pengembangan taman nusa sebagai wisata edukasi sebagai anjang karya atau karyawisata yakni perjalanan yang dilakukan untuk rekreasi juga terdapat aktivitas edukasi atau pendidikan di dalamnya. Dalam aktivitas di Taman Nusa, dari segi pendidikan hal pendidikan atau wisata edukasi banyak yang telah dilaksanakan di areal ini, seperti halnya jika ada pengunjung ingin belajar membatik disediakan alat-alat perlengkapan membatik seperti rumah Japara batik Jawa, ataupun batik kain tenun Bali

Implikasi yang dirasakan terutama bagi wisatawan sebagai sasaran sosialisasi tersebut menuju pada pemahaman tentang keluhuran budaya Nusantara secara umum yang ada di Bali, jugan berimplikasi kepada masyarakat setempat terutama yang terlibat langsung sebagai tenaga kerja, bahkan tidak saja dari daerah sekitar Desa Sidan namun dari berbagai daerah yang ada di nusantara.

\section{KESIMPULAN}

Berdasarkan rumusan permasalahan dan pembahasan hasil penelitian maka kesimpulan yang dihasilkan menunjukan bahwa pola sosialisasi manajemen di Taman Nusa yang ada di Desa Sidan, Gianyar yang dilakukan dengan dua cara, yakni sosialisasi melalui media sosial Instagram dan memanfaatkan kunjungan langsung dari wisatawan. Media sosial mampu mempersempit jarak Media sosial seperti facebook, instagram, website sekaligus dapat menjadi sarana promosi dan pemasaran sehingga menarik minat wisatawan dengan sangat mudah dan praktis. Pola kedua melalui kunjungan langsung dari wisatawan yang datang ke Taman Nusa, umumnya hampir terjadi setiap hari pada jam buka. Umumnya wisatawan yang sudah mengetahui keberadaan melalui media sosial akan datang ke lokasi melalui request kepada pihak Travel yang akan memfasilitasi perjalanan mereka, juga pihak Travel yang menawarkan paket perjalanan yang salah satunya berkunjung ke Desa Sidan, Gianyar untuk melihat dan belajar mengenai wisata edukasi dengan bisa melakukan workshop di areal Taman Nusa ini, Beberapa implikasi sosialisasi bagi wisatawan dan masyarakat setempat adalah mengenal budaya daerah asal wisatwan Nusantara dan mendapat pemahaman secara global tentang dunia pariwisata melalui wisata edukasi ini yang dalam hal ini adalah memahami keragaman adat serta budaya yang ada di Indonesia. 
Berdasarkan kesimpulan diatas maka dapat disarankan hal-hal sebagai berikut:

1. Kepada masyarakat pemerhati pariwisata Bali hendaknya lebih menggalakkan promosi di daerah-daerah yang masih kurang mendapat perhatian, karena dilihat dari lokasinya memang agak jauh dari daerah wisata. Hal ini dapat membantu terutama bagi wisatawan yang mengamati segala aspek kehidupan sosial kultural masyarakat Nusantara khususnya yang ada di Bali.

2. Kepada kalangan akademisi dan praktisi hendaknya mampu membuat suatu pedoman tentang wisata edukasi untuk memberikan pemahaman yang mendalam kepada masyarakat maupun wisatawan agar memahami wisata edukasi.

3. Kepada pemerintah hendaknya lebih memprioritaskan sektor budaya dan panorama alam sebagai pondasi pariwisata khususnya di Bali. Hal ini penting untuk merubah paradigma masyarakat awam bahwa pariwisata hadir bukan sebagai pendegradasi budaya yang beraneka ragam menjadi sekuler melainkan memperkuat eksistensi budaya Bali.

\section{Ucapan terima kasih}

Ucapan terima kasih disampaikan kepada Litabmas IPBI yang sudah bersedia mengakomodasi kebutuhan riset tentang strategi promosi destinasi wisata edukasi Taman Nusa Tulikup Gianyar sampai dengan selesai dalam bentuk artikel ilmiah.

\section{DAFTAR PUSTAKA}

Astiti, Putra Tjok Istri. 2010.Desa Adat Menggugat Dan Digugat. Denpasar : Udayana University Press.

Mantra, IB 1996. Landasan Kebudayaan Bali. Denpasar : Yayasan Dharma Sastra.

Tim Penyusun, 2007. Kamus Besar Bahasa Indonesia. Jakarta: Balai Pustaka.

Nurul Zuriah. 2009. Metodologi Penelitian Sosial dan Pendidikan. Jakarta: Bumi Aksara.

Poearwadarminta, WSJ. 1984. Kamus Umum Bahasa Indonesia. Jakarta: Balai Pustaka.

Paludi, Salman, 2016. Analisis Pengaruh Electronic Word Of Mouth (E-Wom) Terhadap Citra Destinasi, KepuasanWisatawan, Dan Loyalitas Destinasi Perkampungan Budaya Betawi (PBB) Setu Babakan Jakarta Selatan. Tesis, MM IBN Jakarta.

Pitana, I Gde dan Diarta, I Ketut Surya, 2009. Pengantar Ilmu Pariwisata, Yogyakarta: Penerbit ANDI

Prasiasa, Dewa Putu Oka, 2013. Destinasi Pariwisata Berbasis Masyarakat, Jakarta, Salemba Humanika.

Jurnal Abdimas BSI (jurnal Pengabdian kepada Masyarakat) Vol.1 Februari 2018, hal.45-54 yang berjudul Upaya mewujudkan wisata Edukasi di Kampung Tulip Bandung oleh Harry Hermwan, Erlangga Brahmanto, Musafa, Suryana

Sugiyono, 2010. Metode Penelitian Kuantitatif KualitatifDan $R \&$ D.Bandung: Alfabeta.

www.banyuwangitourism.com (diakses pada 2 Februari 2020)

www.banyuwangikab.go.id (diakses pada 4 Februari 2020) 